This is a postprint (final submitted manuscript) version of the following article:

Parris, D., \& Welty Peachey, J. (2012). Building a legacy of volunteers through servant leadership: A case study of a cause-related sporting event. Nonprofit Management and Leadership, 23(2), 259-276. https:// doi.org/10.1002/nml.21047 
Nonprofit Management \& Leadership

WILEY

\section{Building a legacy of volunteers through servant leadership:} A case study of a cause-related sporting event

\begin{tabular}{|r|l|}
\hline Journal: & Nonprofit Management \& Leadership \\
\hline Manuscript ID: & NML-11-0005.R2 \\
\hline Wiley - Manuscript type: & Articles \\
\hline Keywords: & $\begin{array}{l}\text { Nonprofit < Leadership, Nonprofit < Management, Motivation, } \\
\text { Volunters }\end{array}$ \\
\hline \multicolumn{2}{|c}{$\begin{array}{r}\text { SCHOLARONE } \\
\text { ManuSCripts } \\
\end{array}$} \\
\end{tabular}


1

2

3

4

5

6

7

8

9

10

11

12

13

14

15

16

17

18

19

20

21

22

23

24

25

26

27

28

29

30

31

32

33

34

35

36

37

38

39

40

41

42

43

44

45

46

47

48

49

50

51

52

53

54

55

56

57

58

59

60

Building a legacy of volunteers through servant leadership: A case study of a cause-related sporting event 


\begin{abstract}
This study explored the leadership style of the founder of a cause-related sporting event and investigated the effects of this leadership style on motivating volunteers. The National Kidney Foundation (NKF) Surf Festival, which began over 25 years ago to benefit people with kidney disease, was selected as an extreme case because of the longevity and success of the event. Data were collected through semi-structured personal interviews, document analysis, and personal observation. Results indicated that the founder is a servant leader. Three key themes of servant leadership emerged from the data, which influenced volunteer motivation. These were generating a shared vision dedicated to helping others, building a caring and loving community, and creating the freedom and resources for followers to become servants themselves. Our findings also indicated that the spiritual and moral tenets of servant leadership are applicable to secular NPOs. This study contributes to the development of leadership theory as one of the first analyses of servant leadership in a sport context. We conclude by offering suggestions for future research and practice.
\end{abstract}


Non-profit organizations (NPOs) have used cause-related sporting events to connect with consumers and create social capital by linking the company to a relevant social issue (Pope, Isely, and Asamoa-Tutu, 2009; Principle and Thompson, 1999). These events have the multifaceted ability to promote social inclusion, engage a diverse audience, and contribute to wellness (Sherry, 2010). The growth in cause-related events is a consequence of the explosion of NPOs; from 1981 to 2009 the number of NPOs in the U.S. increased 4.7 times reaching over 1.9 million (IRS, 2009). Cause-related sporting events have the explicit goal to generate net profit; however, at the core of these events is the intangible goal of creating positive social change. To make these events successful NPOs need leaders and volunteers who build a legacy of service.

A legacy of dedicated volunteers requires more than hosting a cause-related sporting event. The leaders and the people of an organization, rather than the structure, are the fundamental determinants of organizational behavior (Schneider, 1987). Organizational cultures are created by passing down the founder's values, goals, practices, and behaviors that followers learn over time and then apply to organizational decision-making processes (Schein, 1990). Key to understanding the success of a cause-related sporting event and volunteer motivation is to study the leadership style of the founder. However, there remains little discourse on motivations of stakeholders and the leadership style contributing to the success of these events.

Therefore, the aim of this study was to explore the founder's leadership style of a causerelated sporting event and investigate the effects of this leadership style on motivating volunteers. This investigation focused on the National Kidney Foundation (NKF) Surf Festival, which has achieved a worldwide audience while simultaneously cultivating community-level engagement. Our research questions framing this study were: (a) what is the founder's leadership style; and (b) how has the founder's leadership style contributed to motivating core volunteers 
for over 25 years? By establishing how leadership style influences and motivates volunteers in a cause-related sporting event, we address a significant gap in the leadership literature, and we contribute to the theoretical development of leadership in the NPO sector.

\section{Theoretical Framework}

\section{Leadership Theory}

Two leadership models that have received substantial attention are Bass's (1985) transformational leadership and Greenleaf's (1977) servant leadership frameworks. To understand the differences between these leadership models it is important to discuss two distinct paradigms of leadership, which are distinguished by how the leader views him or herself; as a leader first or as a servant first. A leader first will serve others only after leadership has been established because of a need to fulfill his or her own personal interests (Greenleaf, 1977). The reverse is true for a servant first. Greenleaf described the servant leader as one who is by nature a servant, "the real man, not bestowed, not assumed, and not to be taken away" (Greenleaf, 1977, p. 21). These leadership paradigms are polar opposites and in-between them is an endless variety of human nature (Greenleaf, 1977). Central to this study are servant leadership and transformational leadership - the commonalities and distinctions between their theoretical assumptions have been discussed since the early 1990s.

Transformational leadership was first mentioned by Downton (1973), introduced in a political context by Burns (1978), and proposed as an organizational theory by Bass (1985). Transformational leaders go beyond the exchange of resources, or transactional leadership, by appealing to followers' psychological needs (Bryman, 1992). Transactional leaders manage by contract and reward, focusing on tasks and procedures over personal relationships or building a united vision (Bass, 1990). By contrast, transformational leadership is the process of influencing 
organizational members to change their attitudes and assumptions by building commitment to the organization (Yukl, 1998). Avolio, Waldman, and Yammarino (1991) defined four characteristics of transformational leadership: (a) idealized influence - models vision and mission, imparts trust, pride, and respect; (b) inspirational motivation - communicates high expectations; (c) intellectual stimulation -promotes vigilant, intelligent, rational problem solving; and (d) individualized consideration - mentors followers giving individual attention. The idealized influence characteristic was originally defined by Bass $(1985,1990)$ as charisma motivates followers through personal identification (Yukl, 2010).

Unlike transformational leadership, to date few empirical studies have been conducted using servant leadership. Writing on servant leadership has streamed from Greenleaf's (1977) foundational texts and consists mostly of anecdotal examples (Bowman, 1997; Northouse, 1997). Greenleaf (1977) conceptualized servant leadership as a way of life rather than as a management technique. Servant leadership is distinguished by its primary motivation to serve (what the servant leader does) and self-construction (who the servant leader is), and then from this conscious choice of 'doing' and 'being' one aspires to lead (Sendjaya and Sarros, 2002). Greenleaf admitted servant leadership would be difficult to operationalize and apply. A servant leader's highest priority is serving the least privileged by building an institution that places people first. Trust is developed by the leader selflessly serving others while helping followers grow, which inspires followers to become servants themselves (Greenleaf, 1977).

Although many writers have decoded Greenleaf's work into conventional bullet point lists of attributes and conceptual models, none of them fully capture the essence of Greenleaf's conceptualization of the servant leader (Spears, 1998; Patterson, 2003; Prosser, 2010). Thus, the data in this study will be discussed in relation to Greenleaf's work and Laub's (1999) 
Organizational Leadership Assessment (OLA). The OLA operationalized servant leadership as the following: a) values people - believing, serving, and non-judgmental listening to others; b) develops people - providing learning, growth, encouragement and affirmation; c) builds community - developing strong collaborative and personal relationships; d) displays authenticity - being open, accountable, and willing to learn from others; e) provides leadership - foreseeing the future, taking initiative, and establishing goals; and f) shares leadership - facilitating and sharing power. The willingness to serve others is a common theme infusing all models of servant leadership (Sendjaya, Sarros, and Santora, 2008).

Stone, Russell, and Patterson's (2004) comparison of servant and transformational leadership revealed these styles share attributes of influence, vision, trust, respect, risk sharing, integrity, and modeling; however, the primary difference between them is the leader's focus. According to Stone el al., servant leaders focus more on the people of the organization while transformational leaders focus more on organizational objectives. Both styles stress individual consideration and appreciation of followers, but servant leadership gives greater prominence to serving followers (Stone et al., 2004). In contrast, transformational leaders' primary focus is on building organizational objectives, with the development of followers as the secondary focus (Yukl, 1998). Another distinction is how these leaders influence followers. A servant leader gains influence through servanthood, whereas the transformational leader relies on charisma, enthusiasm, expertise, and strength of relationships (Bass, 1990; Stone et al., 2004).

Additionally, empirical studies have confirmed that servant and transformational leadership are distinct constructs (Liden, Wayne, Zhao, and Henderson, 2008; Parolini, Patterson, and Winston, 2009). Parolini et al.'s (2009) discriminant analysis revealed the following distinct characteristics, with the first focal point of each characteristic linked to servant 
leadership and second to transformational: a) moral distinction (separate values versus collective values), b) focus distinction (individual versus organization), c) developmental distinction (serve versus lead), and d) influence distinction (freedom versus control). Scholars stress the morality of servant leadership and the absence of morality of Bass's (1985) conceptualization of transformational leadership (Parolini et al., 2009). Graham (1991) argued transformational leaders are not concerned with the moral development of followers. Giampetro-Meyer, Brown, Browne, and Kubasek (1998) highlighted that transformational leaders' focus on aligning their needs with the good of the organization may result in narcissism. In contrast, servant leadership is grounded in the values of humility, authenticity, interpersonal acceptance, and unconditional love, where service as well as power is a gift (Van Dierendonck, 2011). The difference between these leadership styles is a function of the organizational context and the leader's personal values (Stone et al., 2004).

\section{Volunteer Motivation}

Volunteer participation is essential for NPOs to offer services (Fisher and Ackerman, 1998). Research regarding volunteer motivation centers on individual socioeconomic and psychological traits ignoring social and organizational contexts (Smith, 1994). Dimensional models are used to explain the helping behaviors of volunteers. First, two-dimensional models use egoistic (motivated to gain benefits or to fulfill social pressures) or altruistic (genuinely care about others) motivations in explaining volunteer motivation (Bendapudi, Singh, and Bendapudi, 1996). Second, three-dimensional models define motivations as altruistic, material, and social (Taylor, 1995). Finally, Monga (2006) employed a five-dimensional model examining altruistic, material, social, affiliation, and egoistic motivations, finding the strongest motive for 
volunteering at special events was affiliation (i.e., passion and attachment to the event and attraction of the ambience of the event).

Individuals are social beings whose interaction with their surroundings shape their values, social constructs, and world view (Mead, 1934). Research shows group affiliation is the catalyst for volunteering (Haski-Leventhal and Cnaan, 2010; Wilson, 2000). However, minimal research exists addressing the effects of leaders on volunteer motivation. In addition, limited research has examined the mechanisms of servant leadership that lead to organizational outcomes; however, Ebener and O'Connell (2010) identified culture building and structural initiatives used by servant leaders' as important in fostering organizational citizenship.

\section{NKF Surf Festival}

Our research was set in the context of the NKF Surf Festival, a project of Richard Salick, a professional surfer, and his twin brother Philip, who donated a kidney to save Salick's life. In 1973, after qualifying for the World Championships, Salick's health declined and he was faced with dialysis treatments. His physicians said he would never surf again; however, after a kidney transplant in 1977, he re-entered competition (NKF, 2010). To improve the lives of people with kidney disease, the Salicks created a surf tournament to raise money and awareness. Their first event raised $\$ 125$ for the local dialysis center. The event has grown to the largest charity surfing competition in the world involving over 300 volunteers and raising more than $\$ 4$ million to help people with kidney disease.

\section{Method}

We used qualitative case study methodology to analyze the founder's leadership style and its effects on volunteer motivation. As our aim was to elaborate leadership theory, we searched for an extreme case (Pratt, Rockman, and Kaufman, 2006). We selected the NKF Surf Festival 
because the founder's and core volunteers' dedication for over 25 years is an anomaly in the nonprofit sector, which faces high volunteer and staff turnover (Eisner, Grimm, Maynard, and Washburn, 2009; Tierney, 2006). In addition, a surf contest is a unique sport setting in the nonprofit sector (Edwards and Kreshel, 2008), where little discourse has occurred on causerelated action sporting events which target subcultures. Built around the surfing culture, the event has been14 times more financially successful than the average cause-related sporting event (Higgins and Lauzon, 2003). These factors contributed to our selecting the Surf Festival as an extreme case. The first author has also volunteered with the NKF for five years, building trust with the organization.

\section{Data Collection}

Data were collected through: a) semi-structured personal interviews, b) document analysis of public materials pertaining to the event, and c) personal observations (Lincoln and Guba, 1985). We conducted 19 interviews, which included the founders, the CEO, board members, employees, sponsors, competitors, and volunteers. Purposive sampling was used to select participants based on their involvement with the event to ensure individuals displaying certain attributes were included in the study (Berg, 2001). Based on the guidelines of Lincoln and Guba (1985), interviews were conducted in a semi-structured format - an interview guide provided structure while questions were allowed to emerge over the course of the interview. Interviews were conducted by the first author in a private setting, lasted between 40-90 minutes, were recorded and transcribed verbatim. The first author documented personal observations in a reflective journal to extend the understanding of the social dynamics (Glense, 2006).

\section{Data Analysis}

Open, axial, and selective coding was used to analyze the data and to form conceptual codes (Creswell, 1998; Strauss and Corbin, 1990). During the initial stage of analysis, open 
coding was utilized to condense data into preliminary categories. For example, several open codes encompassed: a desire to serve (moral calling); the leader as facilitator (sharing power and serving other's needs before one's own); personally committed spiritually liberated (dedicated to the mission, but free to leave); develops people (through encouragement and affirmation); builds community (creating a community of leaders); provides leadership (generates shared vision), and volunteer motivation (service to others, affiliation, and shared ownership). In congruence with Miles and Huberman (1994), some codes were assigned based on leadership theory (i.e., Greenleaf, 1977; Laub, 1999) while others emerged from the data. Next, we organized the open codes into axial codes (the themes presented in the findings and discussion section), by clustering the codes together to discover analytic categories (Neuman, 2006). Finally, selective coding was employed to integrate the data to support the emerging conceptual codes (Creswell, 1998).

Trustworthiness is defined as "how accurately the account represents participants' realities" (Creswell and Miller, 2000, p. 124). A study has trustworthiness if the investigation has credibility, transferability, dependability, and confirmability (Schwandt, 2007). Credibility (similar to internal validity) was established by using triangulation and by conducting member checks with participants, where they reviewed transcripts, interpretations, and provided feedback (Janesick, 1994). Transferability (similar to external validity) was achieved by the first author keeping a reflective journal that provided a contextual narrative (Lincoln and Guba, 1985). In order to improve dependability (similar to reliability) and confirmability (similar to objectivity), the second author, who was not involved in data collection, served as an auditor and reviewed all codes, analyses, and interpretations (Erlandson, Harris, Skipper, and Allen, 1993).

\section{Findings and Discussion}




\section{The Founder as a Servant Leader}

Our first research question sought to discover the founder's leadership style. Findings indicated that the founder is a servant leader as a result of meeting Greenleaf's (1977) and Laub's (1999) conceptualization of servant leadership. As such, the founder (a) is a servant first; (b) displays unconditional love and a moral calling to serve; (c) inspires others to serve through his love; and (d) is committed to helping others, not to the organization, while having a positive impact on the least privileged in society.

Leader as servant first. Salick is a servant leader because his leadership materialized from his desire to serve. Transformational and transactional leadership are defined by what the leader does, whereas servant leadership is distinguished by both its primary motivation to serve (what leaders do) and self-concept (who leaders are) (Sendjaya and Sarros, 2002). Faced with the adversity of having kidney disease, Salick turned his transplant success and his knowledge of the surf industry into an event to help others.

Salick was first a servant and then he made the conscious choice to lead. When asked to describe his job, Salick revealed how helping others led to self-fulfillment:

I have been doing this for 37 years in one way or another since the first transplant. I just sit and wonder, 'God what I am going to do . . . for a career.' I have been sitting in my career for a lot of years

It is important to note that "servant leadership is not about self-sacrifice or self-denial. It is about self-fulfillment" (Keith, 2008, p. 68). Since his first transplant, loving and helping others is what Salick and his followers do, and it is who they are. Being a servant leader is a way of being that is part of one's psyche, as it goes beyond knowledge and skills and requires an internal transformation (a paradigm shift) and the will (a choice) to make life better for others, rather than 
for one's self (Greenleaf, 1977). Above all other attributes, the primary focus on service distinguishes servant leadership from other leadership theories (Prosser, 2010), which Salick exemplified here.

Displays unconditional love and a moral calling to serve. Salick's service begins with his love for people and a moral calling to help, which are essential attributes of servant leaders (Keith, 2008). Greenleaf (1977) argued serving others requires unconditional love and a community. All study participants emphasized the founder's love for others, using words such as love, kindness, empathy, compassion, consideration, and care. A NKF staff member's quote is representative of many participants' comments regarding Salick: "he's the kind of person that has compassion for everybody, not just people with kidney disease." When asked why people volunteer at this event, one volunteer affirmed that "I think that in this group of people [long pause ... started crying] . . . they love Richard [Salick]. " The leaders' and followers' agapaó (love) for others was expressed by participants, including the founder, not just in their words but also in their tears and actions. Our findings parallel Patterson's (2003) leader-to-follower and Wintson's (2003) follower-to-leader servant leadership models, which start with a person's agapaó for others and end with service. The leader makes the conscious choice to value others first and models this by behaving humbly and altruistically (Laub, 1999; Winston, 2004). In contrast, transformational leaders focus on the organization and influence through charisma and control (Parolini et al., 2009).

Inspires others to serve through love. Salick is a servant leader because his love inspires others to serve. Servant leaders model the axiom 'love is as love does' (Russell and Stone, 2002). For example, a volunteer of 12 years said that Salick is "a leader of a different kind. . . . People feel very honored to watch this man in action, because . . he walks the talk." If 
one is tired, as a volunteer of 37 years pointed out, all one needs to do is find Salick, because despite having had three transplants, "he actually physically does the work . . he is the ox underneath the cart that carries all the weight." All participants provided examples of how Salick's servanthood influenced them by displaying authenticity and valuing people (Laub, 1999). Participants acknowledged, although with less emphasis, his charismatic abilities, enthusiasm, and strength of relationships, which are transformational leadership qualities (Bass, 1990). However, Salick's inspiration comes from serving others, and this became evident after participants told their stories of how his service to them and others helped them see how they could serve, too.

Servant leadership is contagious and has a transforming influence (Farling, Stone, and Winston, 1999; Sendjaya et al., 2008). The comments of a young volunteer with kidney disease represent what it is like to be around the founding brothers: "they're always having fun and it's just contagious." In support of Winston (2004), we found that Salick's agapaó and service inspired followers' to become servants. For instance, immediately prior to the event Salick was hospitalized for 14 days, and referring to the volunteers, he said "those guys just took over." All of the original volunteers have become servant leaders, adopting the mission of the founder and championing it.

\section{Committed to helping others, not the organization, while having a positive impact}

on the least privileged in society. Servant leaders' mission is to help others, and organizations are great places to do that; however, organizations do not own them (Greenleaf, 1977). This is distinct from transformational leadership that focus more on organizational objectives (Stone et al., 2004). Although the Surf Festival is hosted with the NKF, direct patient aid is not a mission of the NKF. Salick, with conviction, stated "I will be the first one out of this organization if we 
drop our patient aid." While Salick does not believe the organization is essential, he does believe community is necessary for making a difference. To illustrate this point, the first author observed the volunteers gathering throughout the year to plan, to fundraise, share stories and support each other through weddings, cancer, and funerals. Participants told stories describing the transforming effect of how giving a $\$ 75$ gift card for groceries enables a person on dialysis to keep fighting, and the first author has accompanied the founder to purchase groceries for those in need. Thus, two noteworthy outcomes of the founder's servant leadership are his agapaó for others has inspired followers to be servant leaders, and together as servants they have had a positive effect on the least privileged in society (Greenleaf, 1977).

\section{Building Volunteer Motivation}

Our second research question explored how the founder's leadership style contributed to motivating core volunteers for over 25 years. Salick, a servant leader, motivated his volunteers by (a) generating a shared vision dedicated to helping others, (b) building a caring and loving community, and (c) creating the freedom and resources for followers to become servants themselves. Understanding the mechanisms of how servant leaders foster volunteer motivation can help NPOs grow and develop a volunteer base, create servant-led events and improve overall organizational performance.

Generating a shared vision dedicated to helping others. Servant leadership is based on a commitment to love and serve others, which becomes the mission of the leader and followers (Greenleaf, 1977). All study participants embraced a common mission, as stated by a volunteer of 25 years: "It's all for raising funds for patient services. It's mostly helping the patients." The vision of a servant leader is not based on egocentric ambition; it is driven by a virtuous calling to help others (Lanctot and Irving, 2010; Sendjaya et al., 2008). Each study participant explained 
they volunteered for philanthropic reasons, which supports the volunteer literature that suggests altruistic motivations are prominent for volunteers (Monga, 2006).

Salick encouraged his followers to embrace a service orientation. A long-time sponsor and volunteer articulated the shared calling:

We all have a common goal and it's not for a self-profit. It's to help other people. And when you get a group of people ... whose heart is in the same place, I think you have a lot more in common than you would, say in a workplace.

The association with others who choose to serve first helps form an attachment to the event and an attraction to the culture created by this servant volunteer community. This supports findings that affiliation is a strong motivator in volunteering at special events (Haski-Leventhal and Cnaan, 2010; Monga, 2006; Wilson, 2000). The motivation of serving others illustrates the distinguishing attribute of servant leadership (Russell and Stone, 2002).

Serving others has become a way of life for the volunteers. The event is an integral part of their lives, as illustrated by a sponsor and volunteer for over 25 years, who said "it has been something that you just in your mind could never imagine Labor Day without this particular event." Every study participant spoke about planning vacations around the event and how they have become an extended family. This festival, as one volunteer of 12 years stated, is "a labor of love." Through the founder's service, those served become more likely to become servants (Greenleaf, 1977). This is demonstrated by a young volunteer, who when asked about the future of the event, said "I will put everything that I can towards making it last. And do my best to bring in ... more volunteers." All study participants indicated their commitment to continue the mission of the event while expressing a will to carry on as servant leaders. 
Building a caring and loving community. Although the event is held once a year, the founder and followers are servant leaders year around, which has fostered a loving and caring community. A volunteer for 37 years, who has taken ownership of various parts of the event, pointed out that at "different times we will meet for beer at the surf shop or . . dinner at Norman's . . . you do end up with a . . f fellowship that is shared." The volunteers and founder are an extended community whose ties are as strong as a family. When the first author's mother suddenly passed away, the Surf Festival community pulled together and provided emotional, logistical, and daily needs assistance. As a member of the NKF staff said, "they'll do anything in the world for you if you ask." Greenleaf (1977) argued "the only sound basis for trust is for people to have the solid experience of being served by their institutions" (p. 83). One long-time volunteer tells with tears in his eyes about when he was in a coma, "those guys came every day. ... I did not know that they had a birthday party for me ... they were pulling for me." This personal touch creates a relationship based on love and trust that increases the likelihood of organizational citizenship behavior (Ebener and O’Connell, 2010).

Notable to this community is the multi-generational make-up of the volunteers. This is highlighted by an original volunteer, who said "our long-time volunteers have their kids involved now." Another volunteer, who has started her own NPO, stated "I've seen kids as young as four helping out ... if you get the parents involved ... you can get the kids involved." Salick has built a community of people of all ages, where volunteering for the Surf Festival is an integral part of their social surroundings that shapes their behaviors, perspectives, and values (Mannheim, 1936; Mead, 1934). This multi-generational, volunteer- driven event supports Haski-Leventhal and Cnann's (2010) claim that social and community norms affect an individual's tendency to volunteer. Built around the surfing culture, the founder along with his 
volunteers has created a loving community that shows multiple generations the powerful gift of service.

\section{Creating the freedom and resources for followers to become servants themselves.}

Servant leaders motivate followers by serving them, which entails asking them what are their needs, hopes, and dreams (Greenleaf, 1977). The founding brothers stated that they want volunteers to do what they do best. For example, Salick's brother said "we just ask them. What do you want to do? What would make you happy?" All study participants spoke enthusiastically about the ownership and freedom they are entrusted with to perform multiple roles at the event. The four-day event includes a silent auction, a professional and amateur surfing contest, a VIP party, a press party, a bikini contest, exhibitions, and any big idea that a volunteer wants to try to make the event better. An example of Salick calling forth volunteer talents is when the leader of the silent auction, who works in computer technology, identified the difficulty of tracking auction items and preparing thank you notes. Salick gave her the ownership of the auction, which enabled her to take initiative and design a computer program to automate this process. Also, the leader of beach volunteers revealed the event "has been successful . . . because ... they [the volunteers] really take ownership. . . they divide their tasks and there's a leader ... of the volunteers, there's a leader at the wine tasting, there's a leader . . in the beach area."

The greatest example of ownership is seen in a lifelong volunteer who recently passed away, as recalled by another volunteer; "when you made eye contact . . . or hollered his name ... he was there. ... whatever you needed ... he improved it and no matter what" (16th Street, 2010). As Greenleaf (1977) emphasized, a servant leader is primus inter pares (first among equals), and leadership is not limited to authority figures. This servant-led event has not only empowered its volunteers to take ownership but has given them the freedom and resources to 
become leaders. For over 25 years, Salick's servant leadership has resulted in a core group of volunteers who pass these social and community norms to their children, which is unique in the nonprofit sector that struggles with high volunteer and leadership attrition rates (Eisner et al., 2008; Tierney, 2006). Thus, our findings support Haski-Leventha and Cnaan's (2010) claim that group affiliations influence volunteerism. Through a core group of volunteers, the NKF of Florida has raised millions of dollars, which would not be possible without the long-term support of a multi-generational volunteer base.

\section{Limitations}

A limitation of this study is these results are based on one individual and the findings may not be generalizable. Even though results revealed a positive link between Salick's servant leadership and volunteer motivation, this does not indicate that servant leadership will be effective in all NPOs. Since the data represent the experiences, knowledge, and opinions of the interviewees, this brings the possibility of biases (Miles and Huberman, 1994). By the first author conducting personal observations, document analyses, and the second author reviewing codes and interpretations, we mitigated bias and assisted in providing insight about the organization (Erlandson et al., 1993). Additionally, we tested conclusions with study participants, who confirmed the findings reflected the founder's leadership style and the culture of the event (Lincoln and Guba, 1985).

\section{Implications and Future Research Directions}

From a theoretical standpoint, we provide an empirical example of servant leadership by showing how it can lead to the development of long-term volunteers who then become servant leaders. Our study contributes to the development of leadership theory by providing evidence of the applicability of servant leadership in a NPO sport context. Our work extends previous studies 
in the sport industry which have shown servant leadership to be an effective coach behavior, as athletes being coached by these leaders had an increase in motivation, mental acuity, satisfaction, and performed better than those led by a non-servant leader (Hammermeister et al., 2008; Rieke, et al., 2008; Taylor, 2008; Westre, 2003). In addition, while servant leadership has been associated with religious teachings (Winston, 2004; Ebener and O'Connell, 2010), our results show that the tenets of servant leadership are applicable to a secular organization.

In terms of practical implications, Haski-Leventhal and Cnaan (2010) highlight the importance for NPOs to find new resources for volunteers and to investigate the role of groups in enhancing pro-social volunteer behavior. Our study identifies three leadership mechanisms that NPOs can tap to cultivate long-term volunteer motivation. If servant leadership enhances volunteer motivation, as our findings suggest, NPOs hosting cause-related sporting events should strive to incorporate servant leadership models.

Several intriguing directions for future research emerged from our study. First, researchers can explore how a sporting event can be designed to encourage servant leadership. Second, there is need to investigate how a NPO can create a personal connection with stakeholders to foster a caring and loving community that includes multiple generations. Last, researchers can examine how these events serve as resource tools to empower others to make a difference. 


\section{References}

Avolio, B.J., Waldman, D., and Yammarino, F. “Leading in the 1990’s: The Four I's of Transformational Leadership." Journal of European Industrial Training, 1991, 15(4), 9 16.

Bass, B. M. Leadership and Performance Beyond Expectations. The Free Press, New York, NY, 1985.

Bass, B. M. "From Transactional to Transformational Leadership: Learning to Share the Vision.” Organizational Dynamics, 1990, 18 (3), 19-31.

Bass. B. M. A New Paradigm of Leadership: An Inquiry into Transformational Leadership. Alexandria, VA: U.S. Army Research Instituted for the Behavioral and Social Sciences, 1996.

Bass, B.M. "The Future of Leadership in the Learning Organization.” Journal of Leadership Studies, 2000, 7(3), 18-38.

Bass, B., \& Bass, R. The Bass Handbook of Leadership: Theory, Research, and Managerial Applications. (4th ed.) New York, NY: The Free Press, 2008.

Bendapudi, N., Singh., S.N., and Bendapudi, V. "Enhancing Helping Behavior: An Integrative Framework for Promotion Planning.” Journal of Marketing, 1996, 60, 33-49.

Berg, B. L. Qualitative Research Methods for the Social Sciences. (4 ${ }^{\text {th }}$ ed.) Boston MA: Allan and Bacon, 2001.

Bloye, D., and Smith, A. Sport Policy and Development: An Introduction. London: Routledge, 2009.

Bowman, M.A. Popular Approaches to Leadership. In P.G. Northhouse (eds.) Leadership: Theory and Practice (pp.239-260). Thousand Oaks, CA: Sage, 1997. 
Bryman, A. Charisma and Leadership in Organizations. London: Sage Publications, 1992.

Bruening, J.E. "Coaching Difference: A Case Study of 4 African American Women Student-athletes." Journal of Strength and Conditioning Research, 2004, 18(2), 242-252.

Burns, J. M. Leadership, Harper \& Row Publishers, New York, NY, 1978.

Creswell, J.W. Qualitative Inquiry and Research Design: Choosing Among 5 Traditions. Thousand Oaks, CA: Sage, 1998.

Creswell, J.W. \& Miller, D. L. “Determining Validity in Qualitative Inquiry.” Theory Into Practice, 2000, 39(3), 124-130.

Downton, J.V. Rebel Leadership: Commitment and Charisma in the Revolutionary Process. New York, NY: Free Press, 1973.

Ebener, D. and O’Connell, D. “How Might Servant Leadership Work?” Nonprofit Management \& Leadership, 2010, 20(3), 315-335.

Edwards, H. and Kreshel, P. "An Audience Interpretation of Corporate Communication in a Cause-Related Corporate Outreach Event: The Avon Breast Cancer 3-Day Walk." Association for Education in Journalism and Mass Communication, 2008, 175-244.

Eisner, D., Grimm, R. Maynard, S. and Washburn, S. "The New Volunteer Workforce." Stanford Social Innovation Review, 2009, 32-37.

Erlandson, D., Harris, E., Skipper, B., and Allen, S. Doing Naturalistic Inquiry. Newbury Park, CA: Sage, 1993.

Farling, M.L., Stone, A.G., and Winston, B.E. "Servant Leadership: Setting the Stage for Empirical Research.” Journal of Leadership Studies, 1999, 6, 49-62.

Fisher, R.J., and Ackerman, D. “The Effects of Recognition and Group Need on Volunteering: A Social Norm Perspective." Journal of Consumer Research, 1998, 25, 262-275. 
Giampetro-Meyer., A, Brown., S.J.T., Browne., M.N., and Kubasek, N. "Do We Really Want More Leaders in Business?" Journal of Business Ethics, 1998, 17, 1727-1736.

Glense, C. Becoming Qualitative Researches: An Introduction. (3rd ed.) New York, NY: Pearson, 2006.

Graham, J. "Servant-Leadership in Organizations: Inspirational and Moral.” Leadership Quarterly, 1991, 2(2), 105-119.

Green, B.C. "Sport as an Agent of Social and Personal Change." In Management of Sports Development, edited by V. Girginove. Oxford: Elsevier, 2008.

Greenleaf, R. Servant Leadership. New York, NY: Paulist Press, 1977.

Cnaan, R., and Haski-Leventhal, D. "Group Processes and Volunteering: Using Groups to Enhance Volunteerism.” Administration in Social Work, 2009, 33, 61-80.

Hammermeister, J., Burton, D., Pickering, M. A., Westro, K., Baldwin, N. \& Chase, M. "Servant Leadership in Sport: A Concept Whose Time has Arrived." International Journal of Servant Leadership, 2008, 4, 185-215.

Higgins, J.W. and Lauzon, L. "Finding the Funds in Fun Runs: Exploring Physical Activity Events as Fundraising Tools in the Non-profit Sector." International Journal of Nonprofit and Voluntary Sector Marketing, 2003, 84(4), 363-377.

IRS, Internal Revenue Service, 2009. Retrieved October, 20, 2009 from http://www.irs.gov/ Janesick, V. "The dance of qualitative research design: Metaphor, methodolatry and meaning." In N. Denzin \& Y. Lincoln (Eds.), Handbook of qualitative research (pp. 209-219). Thousand Oaks, CA: Sage, 1994.

Jaworski, J. "Destiny and the leader." In Spears, L. C. (Ed.)., Insights on Servant Leadership: Service, Stewarship, Spirit, and Servant Leadership. New York: Wiley, 1997. 
Judge, T. A., and Piccolo, R. F. “Transformational and Transactional Leadership: A Meta Analytic Test of Their Relative Validity." Journal of Applied Psychology, 2004, 89, 755768.

Keith, K. The Case for Servant Leadership. Westfield, Ind.: Greenleaf Center for Servant Leadership, 2008.

Laub, J. (1999). Assessing the Servant Organization: Development of the Servant Organizational Leadership (SOLA) instrument. Dissertation Abstracts International, 60(2), 308. (UMI No.9921922).

Lanctot, J.D., and Irving, J.A. “Character and Leadership: Situating Servant Leadership in a Proposed Virtues Framework.” International Journal of Leadership Studies, 2010, $6(1), 28-50$.

Liden, R.C., Wayne, S.J, Zhao, H., and Henderson, D. “Servant Leadership: Development of a Multidimensional Measure and Multi-Level Assessment.” Leadership Quarterly, 2008, $19,161-177$.

Lincoln, Y.S., and Guba, E. Naturalistic Inquiry. New York, NY: Sage, 1985.

Mannheim, K. Ideology and Utopia: An Introduction to the Sociology of Knowledge. New York, N.Y.: Harcourt, Brace and World, 1936.

Mead, G.H. Mind, Self and Society. Chicago, IL: University of Chicago Press, 1934.

Miles, M.B., and Huberman, A.M. Qualitative Data Analysis. Thousand Oaks, CA: Sage, 1994.

Monga, M. “Measuring Motivation to Volunteer for Special Events.” Event Management, 2006, $10(1), 47-61$.

National Kidney Foundation (NKF). NKF of Florida, 2010. Retrieved June, 1, 2010 from http://www.kidney.org 
Neuman, W.L. Social Research Methods: Qualitative and Quantitative Approaches. (6th ed.) Boston: Pearson Education, 2006.

Northouse, P.G. Leadership: Theory and Practice. Thousand Oaks, CA: Sage, 1997.

Patterson, K. “Servant leadership: A Theoretical Model.” Dissertation Abstracts International, 64(2), 570. (UMI No. 3082719), 2003.

Parolini, J., Patterson, K., and Winston. "Distinguishing Between Transformational and Servant Leadership.” Leadership \& Organizational Development Journal, 2009, 30 (3), 274-291.

Pope, J.A., Isely, E. S., and Asamoa-Tutu, F. “Developing a Marketing Strategy for Nonprofit Organizations: An Exploratory Study." Journal of Nonprofit and Public Sector Marketing, 2009, 21(2), 184-201.

Pratt, M.G., Rockmann, K.W., and Kaufmann, J.B. "Constructing Professional Identity: The Role of Work and Identity Learning Cycles in the Customization of Identity Among Medical Residents.” Academy of Management Journal, 2006, 49 (2), 235-262.

Principle, H., and Thompson, M. (1999). Brand Spirit: How Cause Related Marketing Builds Brands. Chichester, New York: Wiley, 1999.

Prosser, S. Servant Leadership: More Philosophy, Less Theory. Westfield, IN: The Greenleaf Center for Servant Leadership, 2010).

Reese W.L. Dictionary of Philosophy and Religion. Atlantic Highlands, NJ: Humanities, 1980.

Rieke, M., Hammermeister, J., and Chase, M. "Servant Leadership in Sport: A New Paradigm for Effective Coach Behavior." International Journal of Sports Science \& Coaching, 2008, 3(2), 227-239.

Russell, R. "The Role of Values in Servant Leadership." Leadership \& Organization Development Journal, 2001, 22(2), 76-83. 
Russell, R., and Stone, A.G. “A Review of Servant Leadership Attributes: Developing a Practical Model.” Leadership \& Organizational Development Journal, 2002, 23(3), 145 157.

Schein, E. H. Organizational culture. American Psychologist, 1990, 45, 109-119.

Schneider, B. "The People Make the Place." Personnel Psychology, 1987, 40, 437-453.

Schwandt, T.A. The sage dictionary of qualitative inquiry. ( $3^{\text {rd }}$ ed.) Thousand Oaks, CA: Sage, 2007.

Sendjaya, S., and Sarros, J. "Servant Leadership: Its Origin, Development, and Application in Organizations.” Journal of Leadership and Organizational Studies, 2002, 9(2), 57-64.

Sendjaya, S., Sarros, J., \& Santora, J. "Defining and Measuring Servant Leadership Behavior in Organizations." Journal of Management Studies, 2008, 45(2), 402-424.

Sherry, E. “(Re) Engaging Marginalized Groups through Sport: The Homeless World Cup.” International Review for the Sociology of Sport, 2010, 45(1), 59-71.

16th Street. 16th Street, 2010 Retrieved October, 20, 2010 from http://www.16streets.com

Smith, D. H. "Determinants of Voluntary Association Participation and Volunteering: A Literature Review." Nonprofit and Voluntary Sector Quarterly, 1994, 23, 243-263.

Spears, L. Insights on leadership: Service, stewardship, spirit, and servant-leadership. New York: John Wiley and Sons, Inc., 1998.

Stone, A.G., Russell, R., and Patterson, K. “Transformational Versus Servant Leadership: A Difference in Leader Focus.” Leadership \& Organization Development Journal, 2004, 25(4), 349-361.

Strauss, A., and Corbin, J. Basics of Qualitative Research: Techniques and Procedures for Developing Grounded Theory, $2^{\text {nd }}$ ed. Newbury Park, CA: Sage, 1990. 
Taylor, C. "Using Volunteers in Economic Development." Economic Development Review, 1995, Summer, 28-30.

Taylor, T. "The servant leadership of John Wooden". Ed.D. diss., Pepperdine University ,2008. In Accounting \& Tax Periodicals [database on-line]; available from http://www.proquest.com.lib-ezproxy.tamu.edu:2048 (publication number AAT 3307917; accessed July 11, 2011).

Tierney, T. "The Leadership Deficit." Stanford Social Innovation Review, 2006, 26-35.

Van Dierendonck, D. “Servant Leadership: A Review and Syntheses.” Journal of Management, 2011, 27(4), 1228-1261.

Westre, K. "Servant-leadership in sport". Ph.D. diss., Gonzaga University, 2003. In Dissertations \& Theses: Full Text [database on-line]; available from http://www.proquest.com.lib-ezproxy.tamu.edu:2048 (publication number AAT 3093080; accessed July 11, 2011).

Wilson, J. "Volunteering." Annual Review of Sociology, 2000, 26, 215-240.

Winston, B. E. Extending Patterson's Servant Leadership Model: Explaining How Leaders and Followers Interact in a Circular Model. Servant Leadership Research Roundtable, Virginia Beach, VA, 2003.

Winston, B. E. "Servant Leadership at Heritage Bible College: A Single-Case Study." The Leadership \& Organization Development Journal, 2004, 25(7), 600-617.

Yukl, G. Leadership in Organizations. (4 ${ }^{\text {th }}$ ed.) Prentice-Hall Inc., Upper Saddle River, NJ, 1998.

Yukl, G. Leadership in Organizations. (7th ed.) Pearson Education, Inc., Upper Saddle River, NJ: New Jersey, 2010. 